\title{
The Efficiency of Zakat Collection and Zakat Distribution of Islamic Religious Council Perak (MAIPk) Malaysia
}

\section{Asmah Mohd Jaapar and Nur Husnina Kamarulzaman}

Universiti Sains Islam Malaysia (USIM)

Paper to be presented at the $4^{\text {th }}$ International Conference of Zakat (ICONZ)

7-8 October 2020, Surabaya, Indonesia

\begin{abstract}
The study measures the efficiency of zakat collection and distribution by Islamic Religious Council of Perak (MAIPk) in Malaysia between 2013 to 2017. The efficiency of zakat collection and distribution are important to ensure zakat institution achieves the objective that has been established by the society. Previous studies show that the society still have negative perception in the effectiveness of zakat distribution by zakat institutions, hence affect the level of Muslim's confidence to perform their duties to pay zakat through the institutions. This research applied two-stage DEA analysis to measure the efficiency of zakat collection and distribution. The findings form 3 efficiency measures which are technical efficiency, allocative efficiency and cost efficiency for both MAIPk's role of collecting and distributing zakat in Perak. The results show that zakat collection full efficiency is achieved in 2017 while that of zakat distribution is in 2015.
\end{abstract}

Keywords: Efficiency, Zakat collection, Zakat distribution, DEA analysis

\section{INTRODUCTION}

This research analyses the efficiency of zakat collection and zakat distribution of MAIPk Malaysia. In general, zakat management in Malaysia is under the jurisdiction of the state as set out under the Federal Constitution in the Ninth Schedule, List 2 under the State List, which listing matters related to the will, zakat, baitulmal and so on. Therefore, each state has its own zakat administration and management bodies to ensure the zakat funds is wellmanaged, hence could contribute to economic development either as a corporate body or under the supervision of State Islamic Religious Councils. However, some zakat institution has not been able to gain public trust especially from Muslim community on their effectiveness in managing zakat collection and consequently reaching the targeted asnaf group to distribute the zakat (Ahmad Fathi, Hairunnizam, \& Mohd Ali, 2017).
Nowadays, people are very concerned about the efficiency of zakat institutions. Ab Rahman, Alias, \& Syed Omar (2012) stated that the zakat management system needs to be enhanced or strengthened to tackle the problem of inefficiency, particularly in the distribution aspect. The public has constantly raised issue concerning the inefficient allocation of the zakat collection that needs to be tackled to ensure the administration of zakat funds is on the right track.

There were public complaints that zakat has not reached the target groups owing to the absence of advertisement from the authority and lack of understanding from the part of society. It occured due to inefficient management in the zakat distribution aspect. The cause of inefficiency in zakat distribution and zakat collection is due to the management of the institution itself. Sanep \& Hairunnizam (2005) mentioned that there are many studies that have been done regarding the 
perception of zakat institution management. The studies show that the issue of public perception on the effectiveness of the State Islamic Religious Council (MAIN) in Malaysia is one of the factors that reduce the rate of zakat collection in this institution because there are zakat payers who seek alternative ways to pay zakat by allocating the zakat directly to asnaf.

Ab Rahman et al. (2012) stated that in Malaysia, zakat organizations have complimented the government's role in helping poor and needy Muslims. These organisations also improved their management such as infrastructure, human resources, distribution schemes, and the government transparency. However, issues on the inefficient allocation of zakat collections have been raised by the public continuously and create a poor perception on the image of the institution. The efficiency of zakat distribution can be measured by using non-distributable zakat surplus, distribution ratio per collection or from the aspect ratio of surplus to total collection.

There are various reasons that zakat collection failed to reach targeted eligible recipients (asnaf) including inefficient zakat institution, lack of zakat payers and amils, inadequate collection of zakat, as well as technical problems in the allocation of zakat to university students (Abd Wahab and Abdul Rahman, 2012).

According to Ismail and Masturah (2014) the zakat organization itself has contribute to the share of conflicts such as the misappropriations of zakat funds among its own employees that occur from time to time despite the fact that people in zakat governing bodies are thought to have religious backgrounds that are supposed to be righteous and fearful to Allah. The issues on the effectiveness and transparency of zakat management have been consistently raised, particularly as the collections of zakat continue growing each year.

The study examines the efficiency of zakat collection and distribution in one zakat institution in Malaysia. Lack of research on MAIN's performance in Malaysia especially in Perak and its relation to the performance of zakat distribution has motivated this study. The study expects significant relationships between zakat collection and distribution.

\section{The Score of Efficiency}

Efficiency usually relates to output speed relative to system-processed input. Efficiency depicts a system's capacity to generate the highest required output from restricted inputs using accessible technology in an economic context. Therefore, when output rises, the effectiveness will improve, while inputs stay the same or decreased. If it can provide more products and services, an economic system is effective without having to look for more than the funds available. Efficiency is a manufacturing unit that be compared to observe and optimal input and output values, is usually achieved as a maximum weighted output proportion to weighted inputs in a scheme (Abd Wahab and Abdul Rahman, 2012).

Economic theory describes effectiveness as a word for describing how the system performs in producing the output for the specified variable inputs (Farrel, 1957). An economic system is regarded to be effective if it can provide more products and services without seeking more than the funds available. Besides, Farrell (1957) introduced the efficiency measurement model which composed of two parts, namely technical efficiency and allocative efficiency.

According to Kahf (1997), from the economic point of perspective, there are three ways that zakat could influence aggregate supply such as the supply of capital, the supply of labour and the distribution of resources. Zakat funds can be channelled to enhance poor people's health, nutrition and other living circumstances, thereby enhancing the 
labour supply and improving the productivity. The supply of products generated in the economy will subsequently improve as well.

Data Envelopment Analysis (DEA) was used by Sarker and De (2004) to assess farm effectiveness based on distinct farm dimensions and tenures. It chose multiple plants, credit, marketing products and agricultural extensions as outputs and labour costs as input. The research found that most farms are efficient but tiny farms are more efficient than large farms.

Norazlina and Abdul Rahim (2011) measured the effectiveness and governance of zakat organizations using DEA. The study asserted that DEA's features are appropriate for zakat organizations as it has been effectively implemented as an indicator of non-profit and public sector effectiveness.

Moreover, Nur Hafizah and Selamah (2013) analysing the profile and the effectiveness of zakat collection institutions using DEA approach. This research was carried out in three provinces namely Federal Territory, including Kuala Lumpur, Putrajaya, and Labuan. The efficiency findings indicate that the three zakat institutions are effective. The general findings show that the number of zakat payment counter facility needs to be increased to maintain its efficiency and are ready to improve not only the complete collection of zakat, but also the amount of new and current zakat payers. This is because the efficiency of an organization is influenced by the number of zakat collection counters and the number of zakat payers.

According to a study by Faiz, Hairunnizam and Sanep (2014), financial analysis can be used internally to assess issues such as employee performance, operational efficiencies and credit policies and externally to assess the potential investment and creditor credits. From the study, it compares the financial performance of MAIN by using traditional ratio and the cash flow ratio between Islamic Religious Council of Selangor (MAIS) and the Islamic Religious Council of Perak (MAIPk). The aim of the financial analysis is to find irregularities and determine the important measures within the financial position of the Islamic Religious Council of a state.

There are many methods and measurements of efficiency score. Among of them is a non-parametric approach to measure effectiveness. Ismail and Masturah (2014) stated that to measure the efficiency score (ES), it used a DEA model that is a multi-factor productivity analysis model in the presence of multiple inputs and outputs. DEA model utilizes mathematical programming to assess the level of effectiveness for each collection of Decision-Making Units (DMUs) that can be anything from an individual or cost centre to an organisation. Moreover, the total effectiveness is the proportion of weighted collection effectiveness to weighted distribution effectiveness. However, both the collection and the quantity of allocation were regarded as the outputs when running the general effectiveness test. Consequently, the ES has proportionately optimized the input to guarantee maximum score at a specified input to generate a specified output.

\section{METHODOLOGY}

\section{Data Envelopment Analysis}

The efficiency of the Islamic Religious Council of Perak (MAIPk) will be evaluated using the two-stage linked DEA (Data Envelopment Analysis) method. A DEA model may be focused on input and output. By maintaining the proportions of the output constant, an inefficient unit can be converted as an effective unit by proportionally reducing its inputs. On the contrary, in an output-oriented model, an inefficient unit is produced effectively by 
proportionally extending the outputs and maintaining input control.

In stage one, the expenses of zakat collection and other variables of zakat collection efforts are considered as input and the amount of zakat collection as output. In the second stage, the quantity of zakat collection is added to the other distribution variables as input and the quantity of the zakat distribution as output.

DEA is a multi-factor productivity analysis model as described by Talluri (2000) to measure the comparative efficiencies of a homogeneous set of decision-making units (DMUs). From an individual or cost/profit centre to an entire organisation, DMUs can be anything. For this research, the DMUs will be the differences between years of the Islamic Religious Council of Perak (MAIPk).

A combination of the DEA model by Berber Philip (2011), Norazlina \& Abdul Rahim (2011) and Ismail \& Masturah (2014) were adopted to measure the effectiveness of zakat collection and distribution for this research. The model has two stages that are interconnected. However, both stages were distinct by different inputs and outputs. For lucidity, the following section will be discussed the input definitions for both DEA model phases and DEA model formulation.

\section{The Formula of DEA Model}

The efficiency score in the presence of multiple input and output factors is defined as:

$$
\text { Efficiency }=\frac{\text { weighted sum of outputs }}{\text { weighted sum of inputs }}
$$

The fundamental hypothesis in implementing DEA is that if one DMU is able to generate $\mathrm{Y}$ of output using $\mathrm{X}$ of input, other comparable DMUs are anticipated to perform at the same rate if they are effective. Nevertheless, since there are many DMUs, there will be different output rates using different input concentrations. Taking the outputs against all the DMUs' inputs, we can generate a composite DMU (known as a virtual or dummy DMU) that will be the benchmark for evaluating the real DMUs. DEA recognize which of the DMUs are most effective and point out other DMUs inefficiencies.

The DEA model adapted from Ismail and Masturah (2014) is formulated as the following:

$$
\operatorname{Max} h_{0}(u, v)=\frac{\sum_{r=1}^{s} v_{r} y_{r 0}}{\sum_{i=1}^{m} u_{i} x_{i 0}}
$$

Subject to:

$$
\begin{aligned}
& \frac{\sum_{r=1}^{\mathrm{s}} \mathrm{v}_{\mathrm{r}} \mathrm{y}_{\mathrm{rj}}}{\sum_{\mathrm{i}=1}^{\mathrm{m}} \mathrm{u}_{\mathrm{i}} \mathrm{x}_{\mathrm{ij}}} \leq 1 \text { for } \mathrm{j}=0,1, \ldots, n \\
& \mathrm{u}_{\mathrm{i}} \geq 0 \text { for } \mathrm{i}=1,2, \ldots, \mathrm{m}(2.4) \\
& \mathrm{v}_{\mathrm{r}} \geq 0 \text { for } \mathrm{r}=1,2, \ldots, \mathrm{s}
\end{aligned}
$$

Where,

$$
\begin{aligned}
\mathrm{x}_{\mathrm{ij}}= & \text { the amount of input } \mathrm{i} \text { utilised } \\
& \text { by the } j^{\text {th }} \text { DMU } \\
\mathrm{y}_{\mathrm{rj}}= & \text { the amount of output } \mathrm{r} \\
& \text { produced by the } j^{\text {th }} \mathrm{DMU} \\
\mathrm{u}_{\mathrm{i}}= & \text { weight given to input } \mathrm{i} \\
\mathrm{v}_{\mathrm{j}}= & \text { weight given to output } \\
\mathrm{j}= & \text { number of DMU }
\end{aligned}
$$

The inputs for the first stage analysis of zakat collection are the number of amils (Am), the number of branches (Br), the number of agent banks (AgB) and collection expenses (CE) while zakat collection (ZC) will be the output. This model will measure the efficiency of zakat collection.

$$
\mathrm{ZC}=\mathrm{f}_{1}(\mathrm{Am}, \mathrm{Br}, \mathrm{AgB}, \mathrm{CE})
$$

Then, in the second stage, the analysis of zakat distribution included zakat collection (ZC), the number of staff (St) and distribution expenses (DE) while zakat distribution (ZD) will be the output. It will measure the efficiency of zakat distribution.

$$
\mathrm{ZD}=\mathrm{f}_{2}(\mathrm{ZC}, \mathrm{St}, \mathrm{DE})
$$


The study utilises the information on a general basis as a mean of comparison, where all physical and financial resources are used as inputs against both zakat collection and distribution as outputs. The procedures will be comparable to the first and second stage measure where technical, allocative and cost effectiveness will be analysed.

\section{Technical Efficiency}

Technical efficiency shall be evaluated in accordance with the fixed input hypothesis, as a proportion of the observed output to the highest output, or alternative as a proportion of observed input to a minimal input. It is also capable of using physical input to optimally produce outputs without wastage (Zhu, 2003).

Technical efficiency is the efficiency which an output is produced using a given set of inputs. An organization will be technically efficient when it can produce the maximum output from the minimum input quantity such as the number of amils, the number of branches, the number of agent banks and the collection expenses. The data were analysed using Max DEA Software. The technical efficiency scale of $\lambda=1$ demonstrates full efficiency while $\lambda<1$ indicates inefficiency.

\section{Allocative Efficiency}

The definition of allocative efficiency is an indication that the organization makes proportionate use of its input to ensure the minimum cost incurred in order to produce a particular output at a certain input price. A more accurate definition of allocative efficiency is marketed to utilize scarce resources to produce products and provide the services demanded and wanted by society. In order to make a product, the marginal benefit or the amount of money a consumer pays for must be equal to its marginal cost. Thus, when the marginal utility of the good equals to the lowest marginal cost, an optimal distribution is achieved. The full allocative efficiency is when $\lambda=1$ while $\lambda<1$ or $\lambda>1$ indicate inefficiencies.

\section{Cost Efficiency}

Medium marketing targeted at minimizing advertising costs while maximizing product advertising in terms of scope and frequency of exposure to the target market. The cost efficiency is a combination of technical and allocative efficiency. The organization can be only cost efficient if it is both technically and allocative efficient. The score of $\lambda=1$ indicates full cost efficient while $\lambda<1$ indicates inefficient results.

\section{RESULTS AND DISCUSSIONS}

For this study, the data were obtained from the Perak Islamic Religious Council (MAIPk)'s annual report for five years from 2013 to 2017. The variables are the numbers of amils, the numbers of branches, the number of agent banks and the collection expenses to measure MAIPk's zakat collection efficiency.

MAIPk as one of zakat institution that manage zakat is considered as amils and eligible for amils portion. The expensed that is included as amils portion are administration cost (including wages of MAIPk staff), operational cost (including marketing, production, research and development) and tax. Nevertheless, the study is not being able to get access to numerous expenses' details due to confidential issue. As a result, the general expenses were taken as a part of amils' collection expenses as an input and amount of zakat collection as an output.

For distribution efficiency, the variables used as input is distribution expenses (including cost of organizing events to distribute zakat to the asnaf) and the number of employees in the MAIPk's zakat distribution department. The amount of zakat distributed is used as an output. 
MAIPk's Zakat Collection Efficiency

1) Zakat Collection Technical Efficiency

Figure 1 shows the result of technical efficiency for MAIPk's zakat collection from 2013 to 2017. 2017 is the most technically efficient year for MAIPk and 2014 is the least technical efficient. The steady increase in technical efficiency measure from 2014 to 2017 is due to steady increase in zakat collection throughout the years. Meanwhile, some of the input variable like number of agent banks and number of branches maintained the same from 2013 to 2017.

The score of technical efficiency decreased from 0.94365 in 2013 to 0.77586 in 2014 , hence obtained the least technical efficiency score. Among the factors that contribute to the least score in 2014 is the decreased in number of amils by 78 from 2325 in 2013 to 2247 in 2014. Despite the decreasing number of amils, collection expenditures increased by RM12.41 million from RM40.60 million to RM53.01 million. High collection expenses and lack of amils in 2014 lead to MAIPk's technical inefficiency.

For the year 2015 and 2016, the score of technical efficiency increased due to the increased in number of amils and equivalent expenses. Hence, 2017 is the highest technical efficiency of MAIPk's zakat collection which is considered as technical efficiency benchmark.

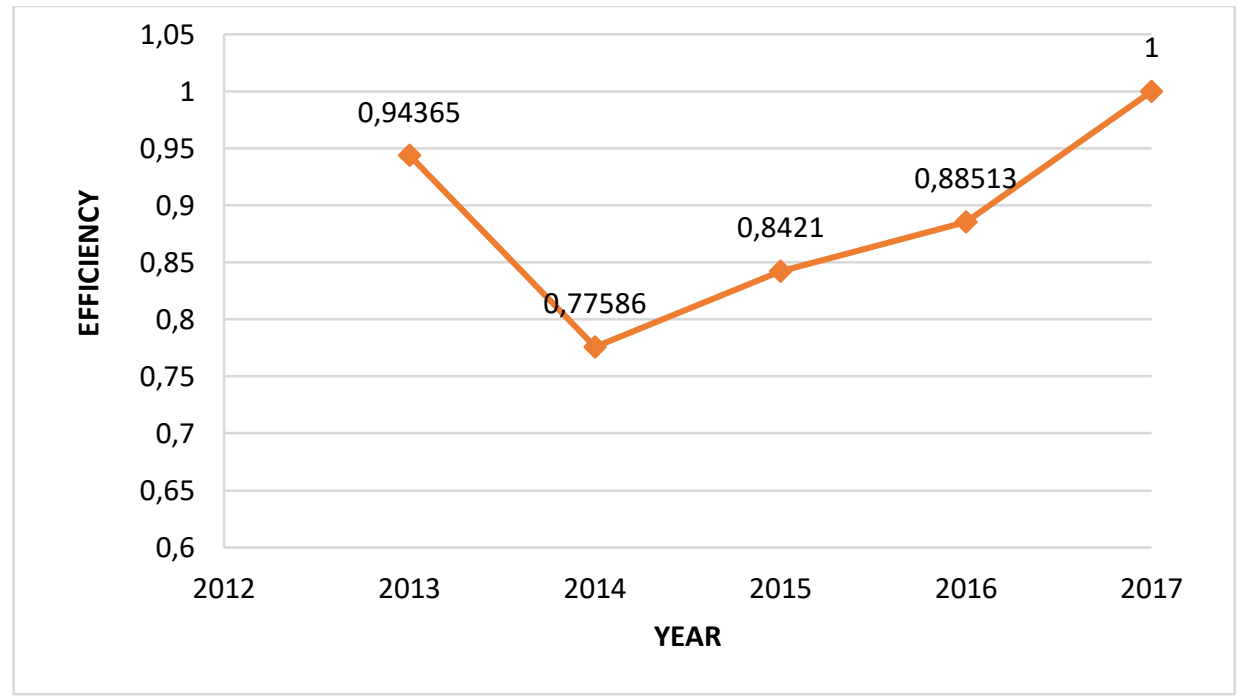

Figure 1. Technical Efficiency for Zakat Collection

2) Zakat Collection Allocative Efficiency

Figure 2 shows the result of allocative efficiency for MAIPk's zakat collection with increasing trend from 2013 to 2017. The result shows that $100 \%$ allocative efficiency for zakat collection is achieved in 2017 whereas 2013 is the least allocative efficient with score around $66 \%$. The increasing allocative efficiency score over the years indicates that Muslim awareness on the obligation to pay zakat has significantly improved. Besides, it also shows that MAIPk are wise in managing expenses for zakat collection and avoid overspending. 2017 become the benchmark year for allocative efficiency as it attained the highest output per unit input. 


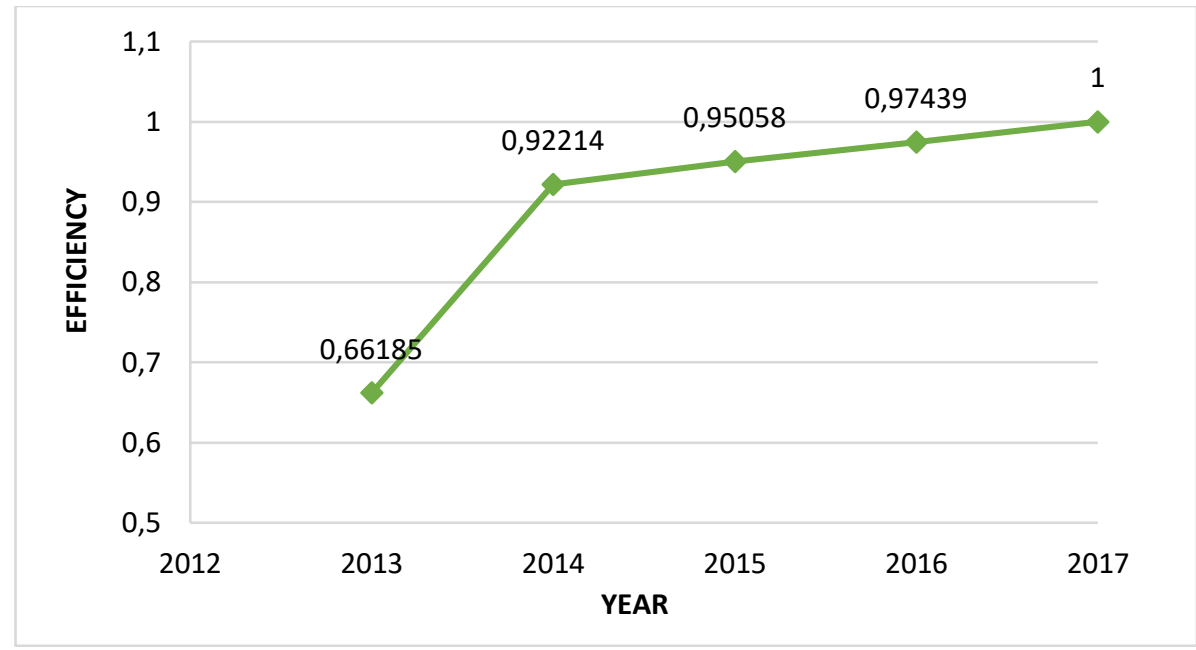

Figure 2. Allocative Efficiency for Zakat Collection

3) Zakat Collection Cost Efficiency

Figure 3 shows the cost efficiency result for MAIPk's zakat collection that consistently increase from 2013 to 2017. Again, 2017 attained $100 \%$ cost efficiency score and 2013 is the least. Zakat collection's cost efficiency has been improved from year to year due to low zakat collection expenses which regard as monetary input despite high number of amil as other input factor. For example, the number of amil in 2013 is 2325 and the total zakat collection expenditure is RM40.60 million while in 2017, the number of amils decreased to 2228 and the total zakat collection expenditure increased to RM58.52 million. Hence, 2017 can serve as the benchmark for the most cost-efficient zakat collection year.

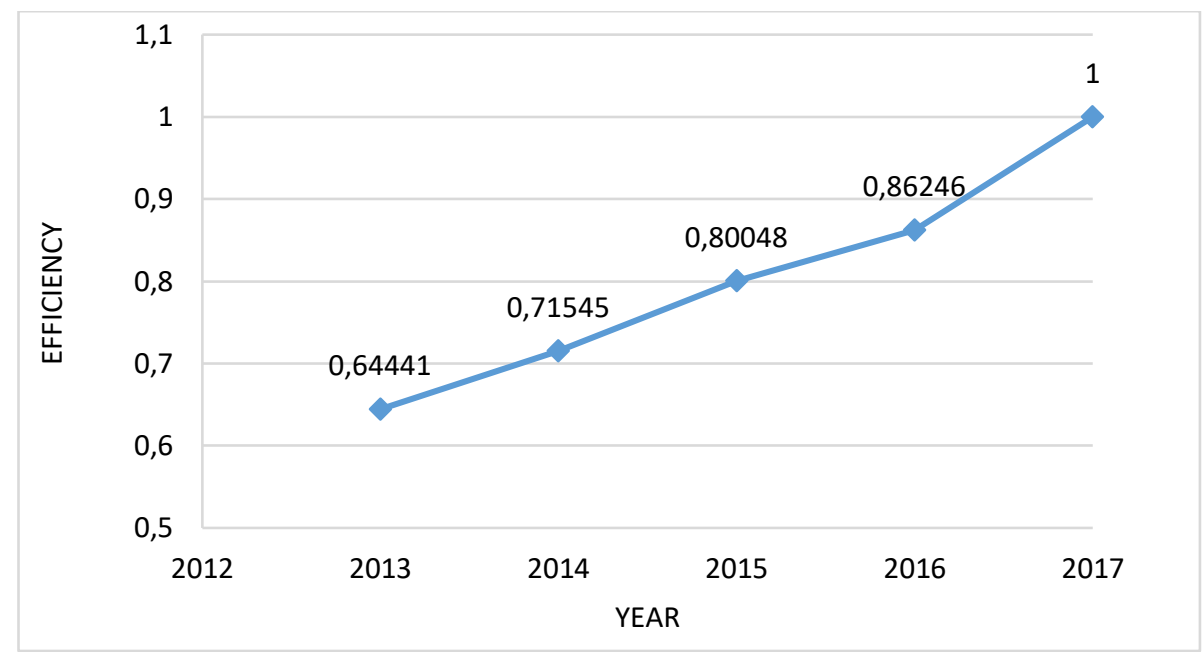

Figure 3. Cost Efficiency for Zakat Collection

MAIPk's Zakat Distribution Efficiency

1) Zakat Distribution Technical Efficiency

Figure 4 shows the result of technical efficiency of MAIPk's zakat distribution from 2013 to 2017. Year
2015 and 2017 attained $100 \%$ technical efficient while 2013 is the least with score around 75\%. 2013 is the least efficient because zakat distribution is the lowest compare to the other year which is RM101.64 million. Moreover 2013 also have the least number of 
staffs compare to other year which is 189 people.

The amount of zakat distribution is increasing from 2013 until 2015 but decrease in 2016. 2015 and 2017 attained full technical efficiency due to the high output, which is zakat distribution, hence could considered as a benchmark year.

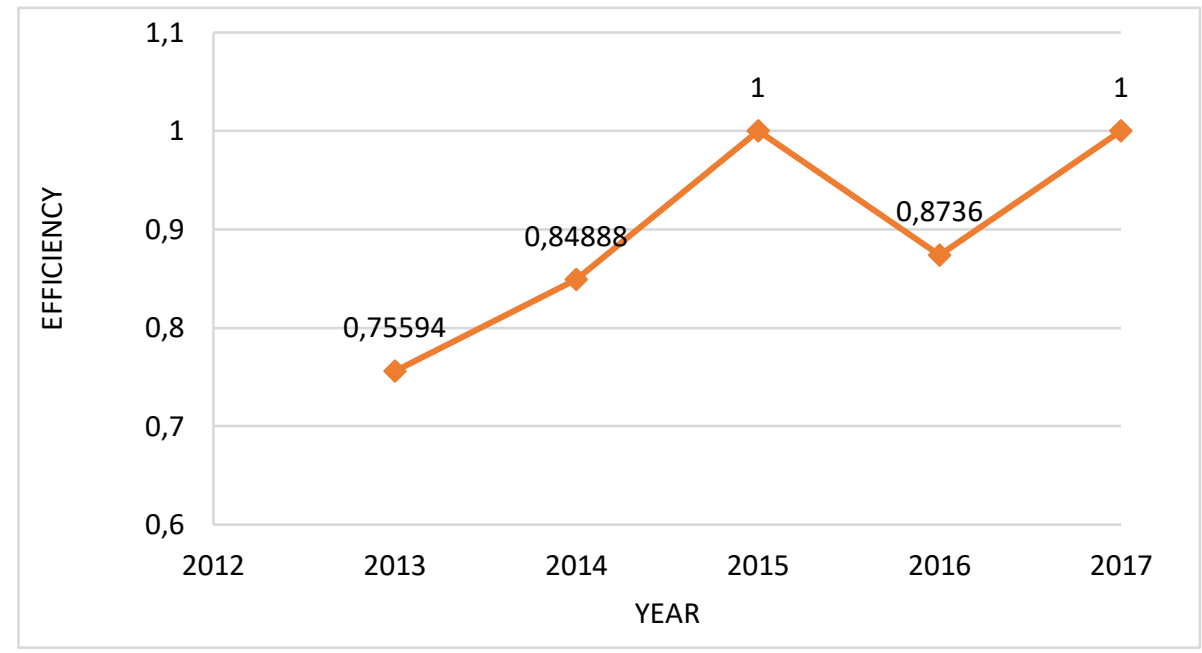

Figure 4. Technical Efficiency for Zakat Distribution

2) Zakat Distribution Allocative Efficiency

Figure 5 shows the score of allocative efficiency for MAIPk's zakat distribution from 2013 to 2017. The result shows that the full allocative efficiency for zakat distribution is in 2015 whereas the most inefficient outcome is in 2017. The decreasing trend of allocative efficiency score from 2015 to 2017 is due to increasing zakat collection (input) against decreasing zakat distribution (output). Therefore, MAIPk should balance the zakat collection as input and zakat distribution as output to avoid inefficiency and significant zakat surplus.

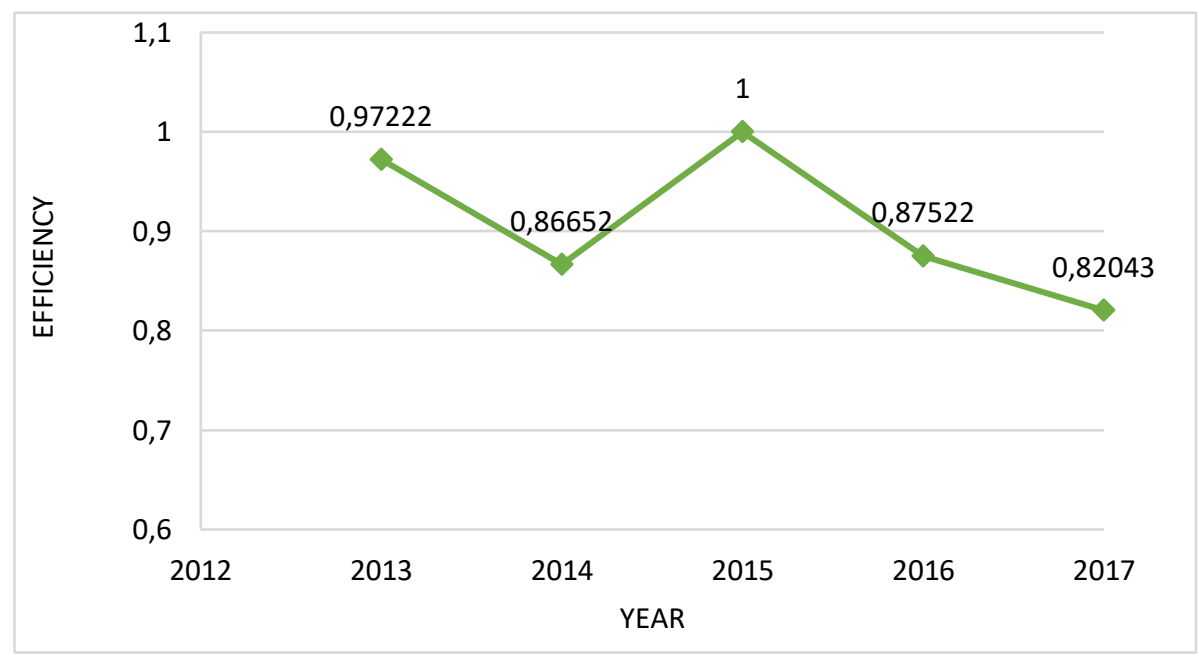

Figure 5. Allocative Efficiency for Zakat Distribution 
3) Zakat Distribution Cost Efficiency

Figure 6 shows the score of cost efficiency for MAIPk's zakat distribution. The result shows that 2015 is considered as a benchmark due to full cost efficient. The least inefficient zakat distribution is in 2013. The cost efficiency score is affected by the amount of zakat collection and zakat distribution expenses. For comparison, consider 2013 versus 2015, the total zakat distribution expenses are RM130.95 million (2013) versus RM155.5 million (2015). The amount of zakat collection is RM118.82 million (2013) versus RM136.31 million (2015) while distributed zakat is only RM101.64 million (2013) versus RM177.14 million (2015). 2013 has significant zakat surplus which distributed in later year like in 2015 which has significant zakat deficit.

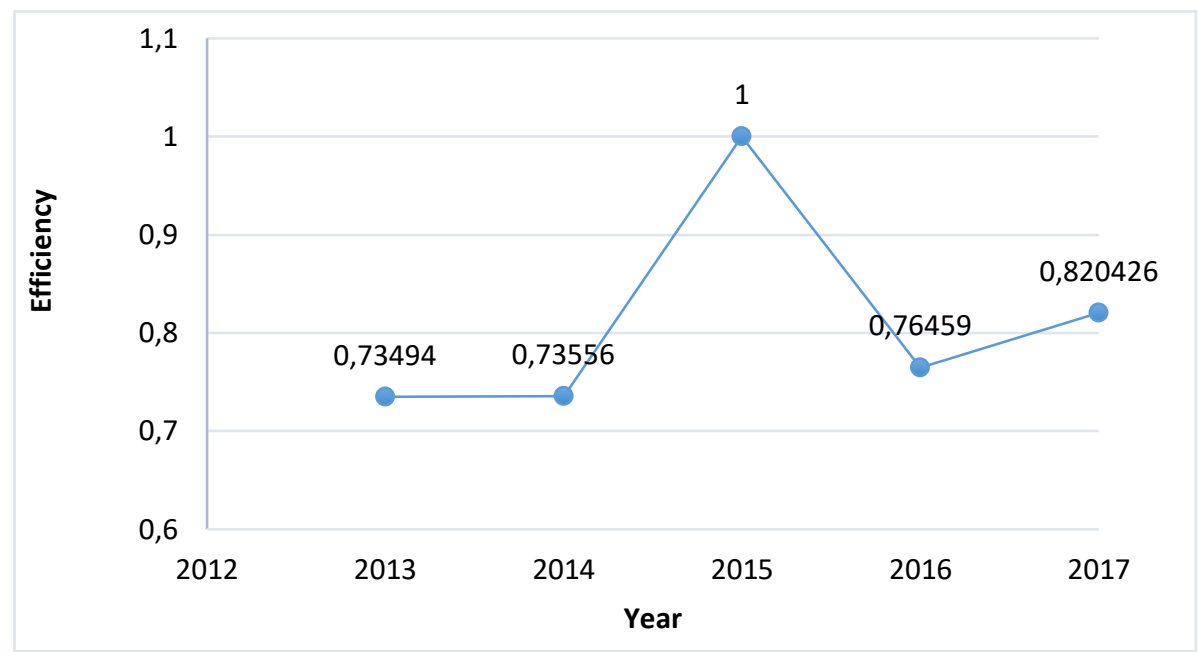

Figure 6. Cost Efficiency for Zakat Distribution

\section{Overall Efficiency}

Eventually, both the first and second stage inputs were combined and correlated with the two outputs which is the amount of zakat collection and zakat distribution. The variables were analysed using Max DEA Software and the finding essentially supported the results of stage one and stage two. The results show that overall zakat collection efficiency is achieved in 2017 while efficiency for overall zakat distribution is in 2015. The result indicates that the efficiencies of one input are underused but overwhelmed by efficiency of other inputs. Therefore, efficiency testing by using a two-stage approach makes it possible to evaluate specific inputs more efficiently than a single-stage method.

\section{CONCLUSION}

Based on the initial research objective, MAIPk able to achieve zakat collection efficiency and zakat distribution efficiency from within 2013 to 2017 although MAIPk is not a privatized zakat organization. This indicates that MAIPk organization is working hard to obtain efficiencies for the zakat collection and zakat distribution. However, the measurements of efficiencies are not an intentional effort in a zakat organization to detect inconsistency or misappropriations of the funds. The outcomes of these scores simply indicate that the DMUs (in this situation MAIPk) can do more than it already done. Therefore, the isolation of collection and distribution functions has provided a better understanding of the efficiencies among these two functions in a related two-stage 
analysis (Ismail and Masturah, 2014). It helps us and the organization to easily identify where MAIPk stands out and where they lag.

Besides, the level of efficiency can be compared from year to year from 2013 to 2017. The comparison of the annual efficiency level can help MAIPk to detect deficiencies that need to be addressed in order to be effectively manage zakat collection and zakat distribution. By using the findings of this study, MAIPk can compare the productivity of services such as actions by the branches and the amils through the benchmark's years.

The allocative and cost efficiency scores should have been more precise and meaningful had this study been given access to details expenses of amils. For example, how much is specifically spent in collection activity such as in talks and campaign seminars in order to raise awareness about zakat and MAIPk's collection outlet. In terms of distribution, the details expenses of amils could be in terms of how much is spent in reaching out the needy and other asnaf categories. Furthermore, the public perception that there is an inefficiency in the collection of zakat and the distribution of zakat can be reduced or denied by the existence of a DEA analysis that shows the MAIPk organization is moving towards greater efficiency from time to time.

\section{REFERENCES}

Ab Rahman, A. S. (2012). Zakat in Institution Malaysia: Problems and Issues. Global Journal al-Thaqafah, 2(1), 35-41.

Abdul Wahab, A. R. (2012). Efficiency of Zakat Institution in Malaysia: An Application of Data Envelopment Analysis. Journal of Economic Cooperation and Development, 33(1), 95-112.
Ahmad Fathi Aminuddin, H. W. (2017). Kecekapan Pengurusan Kewangan dan Pengurusan Agihan Zakat: Kajian Terhadap Majlis Agama Islam Johor. International Journal of Islamic and Civilization Studies, 4(3), 52-66.

Berber Philip, P. L. (2011). Efficiency in Fundraising and Distribution to Causerelated Social Profit Enterprises. Social-Economic Planning Sciences, 45, 1-9.

Faiz M. I, H. \&. (2014). Perbandingan di Antara Majlis Agama Islam Selangor dan Majlis Agama Islam dan Adat Melayu Perak. Proceedings of International Conference Muamalat, Economics \&Islamic Finance, Bangi: Islamic Economics and Finance (EKONIS-UKM).

Farrel, M. J. (1957). The Measurement of Productive Efficiency. Journal of The Royal Statistical Society, 120, 25381.

Ismail Ahmad, M. M. (2014). The Efficiency of Zakat Collection and Distribution: Evidence from Two Stage Analysis. Journal of Economic Cooperation \& Development, 35(3), 133-170.

Kahf, M. (1997). Introduction to The Study of The Economics of Zakah. Economics of Zakah: A Book of Reading, IDB/IRTI, Jeddah: in Kahf, M. (Ed.).

Norazlina Abd. Wahab, A. (2011). A Framework to Analyse The Efficiency and Governance of Zakat Institutions. Journal of Islamic Accounting and Business Research, 2(1),43-62.

Nur Hafizah Ishak, S. (2013). Kajian kecekepan Kutipan Zakat di Wilayah Persekutuan. Prosiding PERKEM VIII, JILID, 414-425.

Sanep Ahmad, H. (2005). Persepsi Agihan Zakat dan Kesannya Terhadap 
Pembayaran Melalui Institusi Formal. Jurnal Ekonomi Malaysia, 39, 53-69.

Sarker Debnaroyon, S. D. (2004). Nonparametric Approach to The Study of Farm Efficiency in Agriculture. Journal of Contemporary Asia, 34(2), 207-220..

Talluri, S. (2000). Data Envelopment Analysis: Models and Extensions. Decision Line, May 2000, 8-11.

Zhu, J. (2003). Quantitative Model for Performance Evaluation and
Benchmarking-Data Envelopment Analysis with Spreadsheets DEA Excel Solver. Kluwer Academic Publisher.

Asmah Mohd Jaapar

Universiti Sains Islam Malaysia (USIM)

asmah.jaapar@usim.edu.my

Nur Husnina Kamarulzaman

Universiti Sains Islam Malaysia (USIM)

nurhusninakz@gmail.com 
